УДК 373

\title{
ИСПОЛЬЗОВАНИЕ КОНСТРУКТОРА ПРИ РЕШЕНИИ ЗАДАЧ РЕАЛИЗАЦИИ НАЦИОНАЛЬНО-РЕГИОНАЛЬНОГО КОМПОНЕНТА ОБРАЗОВАНИЯ ПО ЗНАКОМСТВУ С АРХИТЕКТУРОЙ РОДНОГО ГОРОДА
}

\author{
Виноградова Ирина Викторовна \\ МАДОУ ЦРР Д/С №111 г. Сыктывкара \\ ФГБОУ ВО «СГУ им. Питирима Сорокина»
}

\begin{abstract}
Аннотация: В статье рассматриваются возможности использования конструкторов при решении задач национально-регионального компонента. О знакомстве $\mathrm{c}$ архитектурой родного города дошкольников $\mathrm{c}$ учетом особенностей культурно-исторических традиций народа.

Ключевые слова: национально-региональный компонент, дети старшего дошкольного возраста, конструкторы, развитие конструктивных способностей.

\section{USING THE CONSTRUCTOR IN SOLVING THE PROBLEMS OF IMPLEMENTING THE NATIONAL-REGIONAL COMPONENT OF EDUCATION FOR ACQUAINTANCE WITH THE ARCHITECTURE OF THE NATIVE CITY}

\section{Vinogradova Irina Viktorovna}

Abstract: The article discusses the possibilities of using constructors in solving problems of the national-regional component. About acquaintance with the architecture of the native city of preschoolers, taking into account the peculiarities of the cultural and historical traditions of the people.

Key words: national-regional component, children of senior preschool age, designers, development of constructive abilities.

Как же просто и доступно объяснить пятилетнему ребёнку понятие «архитектура». Как мотивировать его создавать города и архитектурные постройки, которые приносят пользу людям? 
В работе с дошкольниками на сегодняшний день большое внимание уделяется национально-региональному компоненту. В основной образовательной программе дошкольной образовательной организации прописано, что ребенок старшего возраста, 5-6 лет интересуется декоративно прикладным искусством региона, изобразительным искусством, выраженным в произведениях живописи, скульптуре, книжной графики, архитектуры. У ребенка сформированы представления о скульптуре малых форм, необычных архитектурных постройках в городе

Архитектура является сложной научной дисциплиной, которая решает задачи создания пространственной среды для комфортного проживания людей. Построенные объекты не только должны соответствовать прямому назначению, но и приносить пользу человеку.

Много лет мы знакомили детей с известными архитектурными сооружениями и памятниками нашего города, но эти знания не становились системными, при проведении диагностики на усвоение знаний $50 \%$ детей затруднялись назвать здания, 30\% называли по одному (по той причине, что рядом жила бабушка или проезжает мимо него на машине или автобусе) и только 20 \% детей могли узнать по фото и назвать 2-3 здания.

Экскурсии по городу всегда были интересные, и дети внимательно слушали, но ребёнку в силу психологических особенностей нужна не только наглядность, но и действие. Нам в этом помог конструктор «Лего», хотя конструктор может быть и иным. Был объявлен конкурс проектов по конструированию зданий нашего города.

Ребятам совместно с родителями и членами семей было предложено после экскурсии выбрать любое понравившееся здание и сконструировать его дома. Ребята с радостью отозвались и принялись дома конструировать модели архитектурных сооружений нашего города Сыктывкара. Многие дети были уверены в том, что уже на следующий день принесут построенную модель здания. Однако этого не произошло. Многие дома открыли фотографии и совместно с родителями познакомились с историей появления памятников архитектуры, однако как правило на фотографии виден только фасад здания, и когда ребята начинали создавать трёхмерные модели здания, они не знали как здание выглядит слева, справа, сзади, какая у него крыша. Поэтому в семьях было принято решение о совместном посещении памятников архитектуры, фотографировали здание со всех сторон, заходили в них по возможности и фиксировали внутренние помещения, этажность. 
После этого многие ребята попросили родителей вернуться к истории здания, к фотографиям здания разных лет и увидели, что некоторые из них претерпели изменения по разным причинам. И только после этого приступили к конструированию. На этапе конструирования больше сложностей возникало чтобы найти кирпичики «лего» определённых цветов.

Во время конкурса каждый ребёнок-«докладчик» выставлял свою модель и рассказывал о её местонахождении, названии, истории, архитекторе и для чего архитектор строил это здание и что теперь там находится. Здание пожарной каланчи (рис. 1) и здание Академического театра драмы им. В. Савина (рис. 2) стали победителями конкурса.

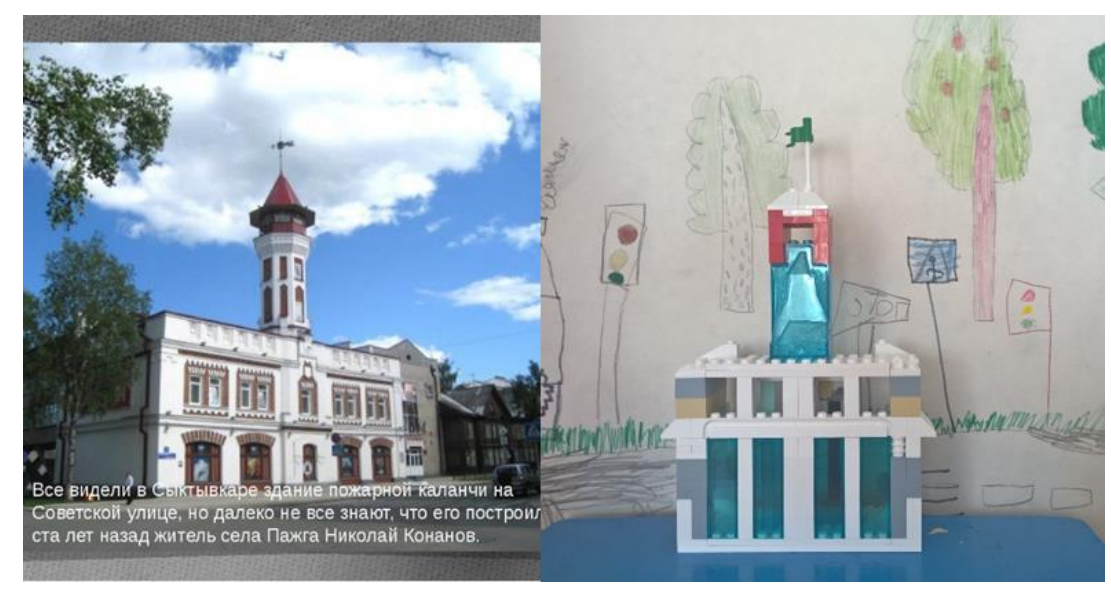

Рис. 1. здание Пожарная каланча

В помещении нашей группы находился музей миниатюр города Сыктывкара.

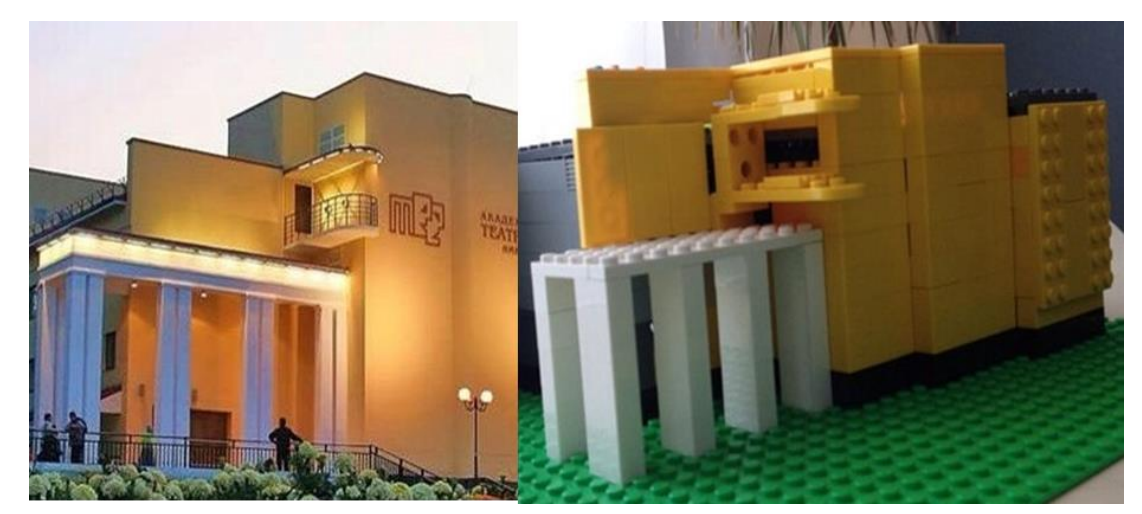

Рис. 2. здание Академического театра драмы им. В. Савина

К концу учебного года ребят еще раз попросили по фотографиям узнать и назвать архитектурные сооружения нашего города: 30\% назвали по 1 зданию, 
$40 \%$ по 2-3 здания и $30 \%$ по 3-4 здания. У детей появился интерес к архитектуре, к истории своего родного города.

Вот так конструкторы помогли реализовать задачи национальнорегионального компонента. Дошкольники усвоили понятие «Архитектура» и обрели интерес к истории города.

Воспитание любви к архитектуре малой Родины не только важная задача содержания современного образования дошкольников, это задача нашего будущего, чтобы дети заботились о сохранении культурного наследия, общекультурных ценностей.

\section{Список литературы}

1. Коноваленко С.В. Развитие конструктивной деятельности у дошкольников / С.В. Коноваленко. - М.: Детство-Пресс, 2012. - 112 с.

2. «От рождения до школы». Примерная общеобразовательная программа дошкольного образования / Под ред. Н.Е. Вераксы, Т.С. Комаровой, М.А. Васильевой. - М.: МОЗАИКА СИНТЕЗ, 2014. 